\title{
A Review on the Mechanism of Reservoir-Induced Seismicity for Nepalese Context
}

\author{
Umesh Raj Joshi ${ }^{1^{*}}$, Ramesh Kumar Maskey ${ }^{l}$ and ${ }^{1}$ Kumud Raj Kafle \\ ${ }^{1}$ Department of Civil Engineering, School of Engineering, Kathmandu University \\ *Corresponding Author \\ umeshrajjoshi54@gmail.com
}

\begin{abstract}
Over 90 cases of Reservoir Induced Seismicity have been recorded around the earth. The magnitude was varying from 3.0 to 6.3 on the Richter scale. A Reservoir Induced Seismicity (RIS) can increase the frequency of earthquakes in seismically active zones and cause a shock in seismically inactive zones. Nepal is situated in a seismically active zone with six large earthquakes of magnitude equal to or greater than 7.6. It increases the risk of RIS, while several storage-type hydropower projects are being proposed in Nepal. Seismic activities recorded around the Kulekhani-I reservoir could be a reservoir induced seismicity. However, consistent data of seismic events and reservoir levels during all phases of filling or drawing of water level is missing. This paper reviews the researches on seismic activities caused by reservoirs or tectonic movements, and the need for the study on the mechanism of RIS for the Nepalese context is identified.
\end{abstract}

\section{Keywords}

Earthquake, hydropower, Reservoir Induced Seismicity, seismicity, tectonic movement

\section{Introduction}

Reservoir Induced Seismicity (RIS) is caused by impounding water by constructing a dam across a river. It also depends on the site's geotechnical and geo-hydrological conditions (Trinh and Panthi; 2014).Earthquakes ranging from 3.0 to 6.3 on the Richter Scale (RS) are noted to be reservoir induced seismicity around the earth (Dojchinovski et al., 2012).

Nepal is situated in the center of the 2400 km long seismically active Himalayan arc. Nepal occupies one-third of the mountain ranges. Nepal is covered by $83 \%$ hills and mountains, and the remaining $17 \%$ by northern alluvial plains at the edge of the great Gangetic Basin. Geologically, Nepal is divided into five tectonic zones from south to north: Terai zone, Siwaliks zone, Lesser Himalayan zone, Higher Himalayan zone, Tibetan-Tethys. The Main Central Thrust (MCT) and the Main Boundary Thrust (MBT) separate the Lesser Himalaya Zone from the Siwaliks, and the Main Frontal Thrust (MFT) separates the Sub-Himalayan Siwalik from Gangetic plains.
The South Tibetan Detachment System (SDS) separates the Higher Himalayan Zone and upper Tibetan-Tethys Himalayan Zone (Dahal, 2010).

Nepal has experienced six large earthquakes (1255, 1408, 1505, 1833, 1934, and 2015) with a magnitude equal to or greater than 7.6 (Thapa 2018). All earthquakes recorded by the National Seismological Center from 1994 to 2019 are shown in figure 1.

\section{Materials and Methods}

\section{The Mechanism of Reservoir Induced Seismicity:}

The mechanism of RIS is found to be mainly influenced by combined factors like lithology, the mechanical parameter of the deep rock mass, the stress state of the rock mass, and pore water distribution. However, the exact cause of seismicity is challenging to find since the occurrence of time cannot be predicted (Weiet al., 2018). The rate of increase in water level, the duration of loading, the maximum reservoir level achieved, and the retention of high levels were 


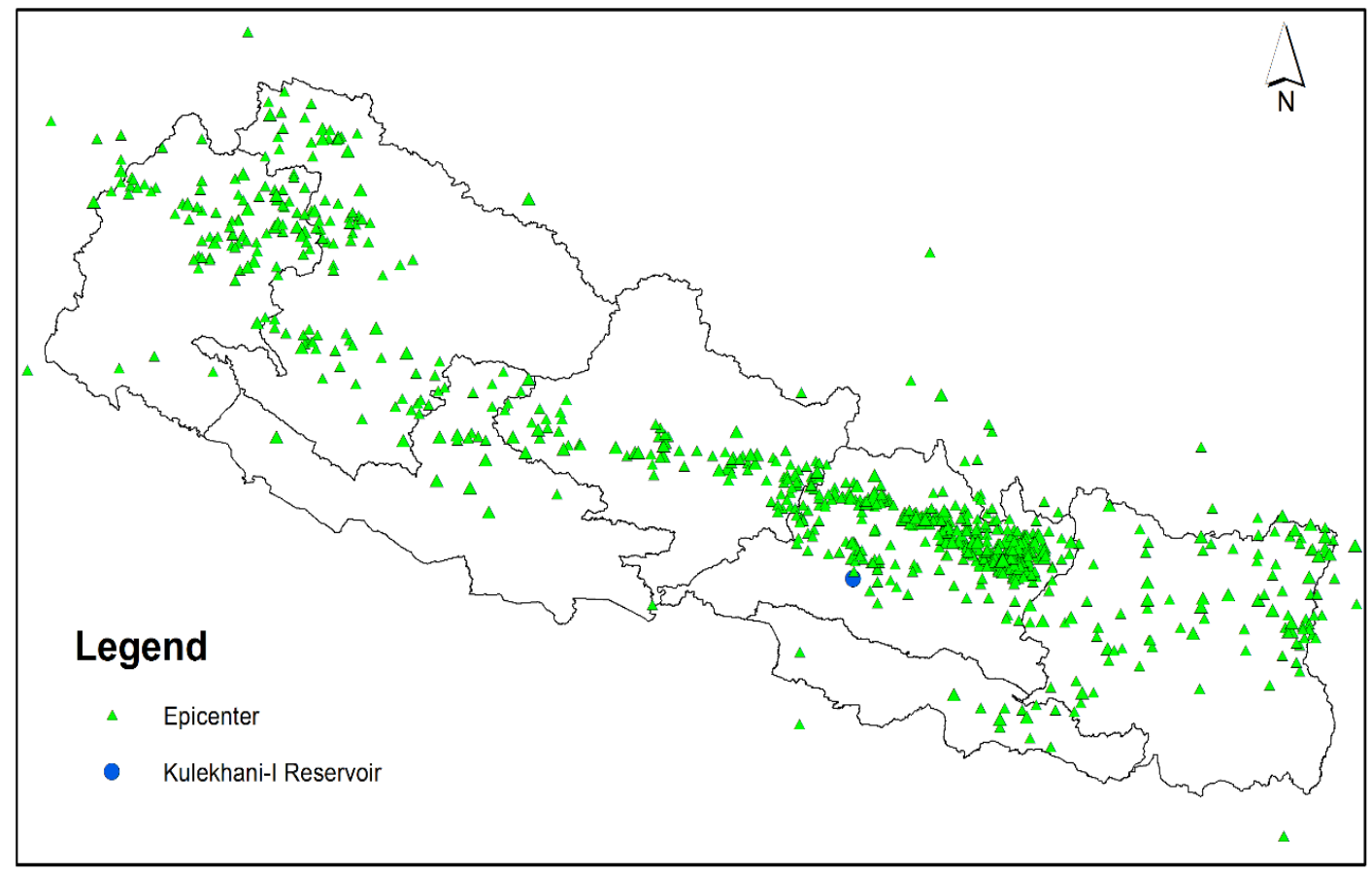

Fig. 1. Epicenters of earthquakes from 1994 to 2019 in Nepal. Kulekhani-I reservoir is seen as a blue dot.

found to be the essential factors in influencing the frequency and magnitude of reservoir induced seismicity (Gupta et al., 1972). Seismicity in the case of pumped storage dams is restricted to shallow depths and low quantities as lake levels are controlled by pumping water from the lower reservoir while in the case where reservoir level depends on annual rainfall, it is challenging to monitor seismicity (Talwani 1997). Based on the first-time lag between the filling of the reservoir and first seismic activity, (Simpson et al., 1988) have classified the RIS in three types:

\section{a) Rapid response}

The seismic activity is observed immediately after the first filling of the reservoir, like in the Reservoir Monticello, Manic-3, Nurek, and Kariba (Simpson et al., 1988).

b) Delayed response

A pronounced increase in seismicity is not observed until many seasonal filling cycles like in the reservoir Koyna, Aswan, Oroville (Simpson et al., 1988).

\section{c) Mixed response}

Both rapid and delayed types of responses may coexist at the same time at any one site.

Similarly, Talwani 1997 has classified the RIS into two temporal categories: initial and protracted seismicity. Initial seismicity is widely observed and is associated with initial impoundment and results from the instantaneous effect of loading (or unloading) and the delayed effect of pore pressure diffusion. In contrast, protracted seismicity is related to the frequency and amplitude of lakelevel changes, reservoir dimensions, and hydromechanical properties of the substratum.

The stresses created by impounding large reservoirs that get superimposed with the preexisting tectonic stresses are supposed to induce seismicity. The pool can either increase the vertical stress due to the weight of impounded water or decrease the effective stress caused by an increase in pore pressure (Simpson 1976). The main factors which may control the induced seismicity, as presented in the paper (Simpson 1976), are summarized in table no. 1 : 
Table 1. Factors Controlling Reservoir Induced Seismicity (Simpson, 1976)

1) Pre-existing stress

- Orientation: tectonic regime (normal, strikeslip, thrust)

- The magnitude of stress: how close to the failure

- Rate of strain accumulation

2) Geological and Hydrological Conditions

Faults:

- Location for reservoir

- Orientation concerning pre-existing and induced stresses

- Failure conditions and permeability

Hydro-mechanical properties of rock:

- Lithology

- Fracture strength

- Fractional characteristics

- Porosity

- Permeability

Hydrological Conditions:

- water table (seasonal variation)

- Accessibility of reservoir water to the groundwater system and faults

- The storage capacity of the groundwater system

3) The Reservoir

Size: Depth (pressure)

Volume (mass)

Shape

Temporal changes in water level: Loading and offloading rate

The general patterns of RIS, as mentioned in the paper (Simpson, 1976), are:

- It is common in the areas of strike-slip or normal faulting.

- Its potentiality is significant in high- to medium strain accumulation, while low in the area of little strain accumulation.

\section{Prediction of Reservoir Induced Seismicity:}

(Wei et al., 2018) suggest several analytical processes like mechanical model method, geological analogy method, probabilistic and statistical method, artificial neural network method, artificial intelligence technique, support vector machine (SVM), and fuzzy support vector machine (FSVM) methods to predict the magnitude of Reservoir Induced Seismicity (RIS). Among these methods, SVM and FSVM are useful in predicting RIS's extent with high accuracy.

(Qiuliang et al., 2018) presents seven methods to predict the magnitude of RIS as:

- Probability Forecasting Model Method

- Fuzzy Comprehensive Evaluation Prediction Method

- Comprehensive Parameter Method

- Logic information Method

- Hierarchical Analysis Method

- Grey Cluster Method

- Neural Network Method

\section{Result and Discussion}

\section{Cases of Reservoir Induced Seismicity:}

The RIS is first noted for Algeria's Quedd Fodda Dam in 1932, while the first extensive study to find the relation between the increased earthquake activity and with the variation in reservoir depth was conducted in the 1940s for Hoover dam (McCully 2001).

Koyna Dam in India has experienced the most damaging reservoir induced seismicity of magnitude 6.3. Also, the Koyna dam has experienced ten earthquakes of $\mathrm{M}>=5$; over 150 earthquakes of $M>=4$ and over 100,000 earthquakes of magnitude $>0$ since 1962 (Gupta, 2002).

According to Gupta 2002, RIS can be grouped in the following categories:

1. Sites with $M>6$ ( 4 cases) (Table no. 1 )

2. Sites with M 5-5.9 (10 cases)

3. Sites with M $4-4.9$ ( 28 cases)

4. Sites with $\mathrm{M}<4$ (53 cases)

The Reservoir Induced Seismicity is mainly observed in the reservoirs with dam height between $100 \mathrm{~m}$ and $150 \mathrm{~m}$, but some reservoirs with height less than $100 \mathrm{~m}$ and greater than 100 $\mathrm{m}$ have experienced RIS like Marathon, Greece $(67 \mathrm{~m})$ and Oroville, USA (236m) (Table 2). 
Table 2. Significant Cases of Reservoir Induced Seismicity (Gupta,2002)

\begin{tabular}{|c|c|c|c|c|c|c|}
\hline $\begin{array}{l}\text { Name of the } \\
\text { dam/reservoir }\end{array}$ & Country & $\begin{array}{l}\text { Height } \\
\text { of Dam } \\
(\mathrm{m})\end{array}$ & $\begin{array}{c}\text { The volume of } \\
\text { Dam }\left(* 10^{\wedge} 6\right. \\
\left.\mathrm{m}^{\wedge} 3\right)\end{array}$ & $\begin{array}{l}\text { Year of Im- } \\
\text { pounding }\end{array}$ & $\begin{array}{l}\text { Year of Larg- } \\
\text { est Earth- } \\
\text { quake } \\
\end{array}$ & $\begin{array}{l}\text { Magnitude of } \\
\text { Earthquake }\end{array}$ \\
\hline Koyna & India & 103 & 2780 & 1962 & 1967 & 6.3 \\
\hline Kariba & $\begin{array}{l}\text { Zambia-- } \\
\text { Zimbabwe }\end{array}$ & 128 & 175,000 & 1958 & 1963 & 6.2 \\
\hline Kremasta & Greece & 160 & 4750 & 1965 & 1966 & 6.2 \\
\hline Hsinfengkiang & China (PRC) & 105 & 13,896 & 1959 & 1962 & 6.1 \\
\hline Srinagarind & Thailand & 140 & 11,750 & 1977 & 1983 & 5.9 \\
\hline Oroville & USA & 236 & 4400 & 1967 & 1975 & 5.7 \\
\hline Marathon & Greece & 67 & 41 & 1929 & 1938 & 5.7 \\
\hline Aswan & Egypt & 111 & 164,000 & 1964 & 1981 & 5.6 \\
\hline Charvak & Uzbekistan & 148 & 2000 & 1971 & 1977 & 5.3 \\
\hline
\end{tabular}

\section{Active Faults and Kulekhani-I Reservoir:}

Major active faults (Fig 2), as shown by Nakata (1982), are in the Himalayan Front, MainBoundary, Lesser Himalayan, and Main Central Thrust Active Fault systems. The concentration of active faults is situated around the southern front of the mountain.

Most of the major existing hydropower reservoir sites are in between the Main Boundary Thrust (MBT) and Main Central Thrust (MCT) that need to be considered from the seismological point of view. The active fault concentration is also situated in this region. If we observe the past major earthquakes, the epicenters of the earthquakes are around these hydropower projects. In the case of the Kulekhani reservoir, the area lies just southeast fromthe active fault that is considered a part of MCT that runs east-west from the southern part of the Kathmandu valley. The intensity of impact is dependent on ground acceleration (mostly ground material dependent) and the

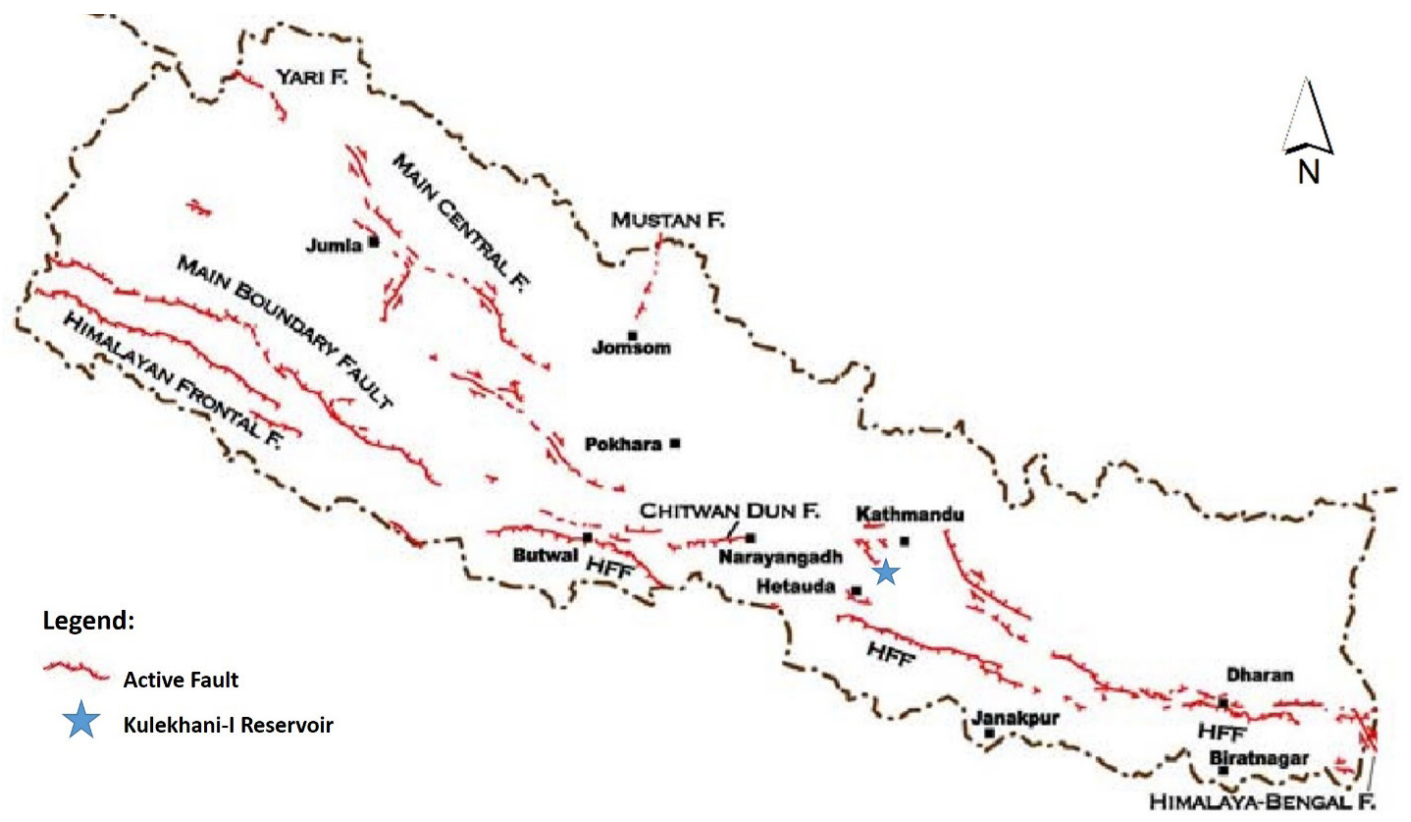

Fig. 2. Active fault distribution in Nepal (Modified after Upreti et al., 2007) 
depth of the focus point. As per seismic hazard map developed by the Department of Mines and Geology (DMG),bedrock peak ground horizontal acceleration is $150-200 \mathrm{~cm} / \mathrm{sec}^{2}$ (150-200 gal) around the Kulekhani area. In most of the Nepal past earthquakes, the focus isthe shallow $(0-70 \mathrm{~km}$ deep) depth that exhibits the most vulnerable at the point of earthquake impact on the reservoir.

\section{Reservoir-Induced Seismicity in Nepal}

There are no reported incidences of Reservoir Induced Seismicity in Nepal, which, according to Gupta and Rajendran (1986), might be due to the presence of a thrust-fault environment in the Himalayan region. However, a series of seismic activities (Table 4 and Fig. 1) have been observed around the only storage type hydropower project in Nepal-Kulekhani-I.

The reservoir height and reservoir volume of Kulekhani and Tanahu hydropower project along with their installed capacity are listed in table 3. The Seismic exploration activity around the Kulekhani reservoir constructed in 1984, started in 2002, with a measured magnitude of 4 (National Seismological Center, 2020) at $76.84 \mathrm{~km}$ from the lake. Since then, several seismic activities have been recorded within the $50 \mathrm{~km}$ radius of the reservoir, shown in table 4.

The frequency of seismic activities has increased after the Gorkha earthquake in 2015, which could be due to the Kulekhani Reservoir as

Table 3. Hydropower projects (Under construction and completed) in Nepal with reservoir height above $100 \mathrm{~m}$

\begin{tabular}{cccccc}
\hline $\begin{array}{c}\text { Hydropower } \\
\text { Project }\end{array}$ & $\begin{array}{c}\text { Capacity } \\
(\mathrm{MW})\end{array}$ & $\begin{array}{c}\text { Reservoir } \\
\text { height }(\mathrm{m})\end{array}$ & $\begin{array}{c}\text { Reservoir Capac- } \\
\text { ity }\left(\mathrm{m}^{\wedge} 3\right)\end{array}$ & Status & Reference \\
\hline Kulekhani-I & 60 & 114 & $85,300,000$ & Completed & ( NEA 2020) \\
Tanahu & 140 & 140 & $806 * 10^{\wedge} 6$ & $\begin{array}{c}\text { Under Con- } \\
\text { struction }\end{array}$ & (Paudel 2020) \\
\hline
\end{tabular}

Table 4. Earthquakes recorded by the National Seismological Center from 1994 within $50 \mathrm{Km}$ diameter from Kulekhani-I (National Seismological Center, 2020)

\begin{tabular}{cccc}
\hline Epicenter & Year (AD) & Magnitude & $\begin{array}{c}\text { The distance of Epicenter from } \\
\text { Kulekhani-I reservoir }(\mathrm{Km})\end{array}$ \\
\hline Dhading & 2007 & 4.3 & 35.64 \\
Dhading & 2015 & 5.1 & 44.75 \\
Dhading & 2015 & 4.5 & 39.45 \\
Dhading & 2015 & 4.5 & 50.06 \\
Dhading & 2015 & 4.7 & 49.20 \\
Dhading & 2015 & 4.5 & 50.06 \\
Dhading & 2015 & 5.2 & 48.56 \\
Dhading & 2015 & 4.0 & 50.65 \\
Dhading & 2015 & 4.0 & 18.75 \\
Dhading & 2015 & 4.6 & 21.46 \\
Dhading & 2015 & 4.3 & 42.11 \\
Dhading & 2015 & 4.5 & 18.45 \\
Dhading & 2016 & 4.2 & 15.60 \\
Dhading & 2017 & 4.0 & 41.00 \\
Dhading & 2018 & 5.0 & 39.08 \\
Dhading & 2018 & 4.8 & 32.82 \\
Makawanpur & 2019 & 4.1 & 4.56 \\
\hline
\end{tabular}


Reservoirs, according to Patrick McCully (2001), could increase the frequency of earthquakes in seismically active zones. In most cases, Reservoir Induced Seismicity has occurred directly beneath the reservoir and most actively within $25 \mathrm{~km}$ from the pool (Simpson, 1976), while in the case of Kulekhani Reservoir, there are five seismic activities recorded within $25 \mathrm{~km}$ from the reservoir, Makawanpur is the closest one.

In Nepal, storage type hydropower projects like Dudh Koshi Storage Hydropower project (640 MW), Tamor Storage (530 MW), Upper Arun (335 MW), Uttar Ganga Storage (300 MW) are being constructed in coming years (Alam et al., 2017). Following the conclusion of Trinh and Panthi (2014), consistent data of seismic activities and reservoir levels should be conducted during all phases of filling or drawing of water level in these storage plants. Therefore, thorough research of RIS is needed in existing reservoirs that could be utilizedto simulate potential RIS in proposed storage type hydropower projects in Nepal.

\section{Conclusion}

Nepal is situated in a seismically active zone. However, Nepal has no studied incidences of Reservoir-Induced Seismicity. The seismic activities around the Kulekhani-I reservoir could be reservoir induced. Therefore, a detailed study of the seismic events around the lake needs to be conducted. Furthermore, research on seismic activities caused either by reservoirs or by tectonic movements needs to be undertaken, and the mechanism of RIS in the Nepalese context has to be understood for the development of storage-type multipurpose hydropower projects.

\section{References}

Alam, F., Alam, Q., Reza, S., Khurshid-UlAlam, S., Saleque, K., and Chowdhury, H. 2017. A Review of Hydropower Projects in Nepal. Energy Procedia, 110, 581-585. DOI: 10.1016/j.egypro.2017.03.188

Dahal, R. K. (n.d.). Engineering Geology of Nepal. Retrieved from http://www.ranjan. net.np/index.php/resources/engineeringgeology-of-nepal2019

Dam-Induced Seismicity. (n.d.). Retrieved from https://www.internationalrivers.org/dam- induced-seismicity

DMG, Department of Mines and Geology, GoV Nepal web: http://seismonepal.gov.np/ ckfinder/userfiles/images/hazard \%20map. jpg

Dojchinovski, D., Olumceva, T., Dimiskovska, B., Pekevski, L., \& Guoxin, W. (2012). Estimating Reservoir Induced Seismicity RIS Potential. Case Study - Kozjak Dam. Retrieved 5, 2020, from http://www.iitk.ac.in/ nicee/wcee/article/WCEE2012_2157.pdf

Gupta, H. K. (2002). A review of recent studies of triggered earthquakes by artificial water reservoirs with particular emphasis on earthquakes in Koyna, India. Earth-Science Reviews, 58(3-4), 279-310. https://doi. org/10.1016/s0012-8252(02)00063-6

Gupta, H.K., 2002. "A review of recent studies of triggered earthquakes by artificial water reservoirs with special emphasis on earthquakes in Koyna, India." Elsevier 279300 .

Gupta, H. K., Rastogi, B.K., and Narain, H.,1972. "Some discriminatory characteristics of earthquakes near the Kariba, Kremasta, and Koyna artificial lakes." Bulletin of the Seismological Society of America 493-507.

Gupta, H. K., and Rajendran,K., 1986. " Large artificial water reservoirs in the vicinity of the Himalayan foothills and reservoir-induced seismicity." Bulletin of the Seismological Society of America 205-215.

McCully, P., 2001. Silenced rivers: the ecology and politics of large dams. London: Zed Books.

National Seismological Centre. Retrieved from http://seismonepal.gov.np/earthquakes

Nakata, T., 1982. "A photogrammetric study on active faults in the Nepal Himalaya." Jour. Nepal Geol. Soc., 2: 67-80.

NEA (National Electricity Authority). Generation, Operation, and Maintenance. (n.d.). Retrieved from https://www.nea.org.np/generation/ index.php?page= $=$ powerhouse $\&$ pid $=15$

Paudel, L. (n.d.). Retrieved from http://thl.com. 
np./index.php?nav=salient

Qiuliang, W., Yunsheng, Y., Jinwu, X., Wenjing, Z., Dun, W., Jinggang, L., \& Lifen, Z.

(2018). Study on Methods of Reservoir Induced Seismicity Prediction of The Three Gorges Reservoir. In Study on Methods of Reservoir Induced Seismicity Prediction of The Three Gorges Reservoir. Retrieved from https://www.iitk.ac.in/nicee/wcee/article/14 S02-034.PDF

Simpson, D. W., 1976. Seismicity changes associated with reservoir loading. Engineering Geology, 10(2-4), 123-150. DOI: 10.1016/0013-7952(76)90016-8

Simpson, D.W., Leith, W.S., and Scholz, C.H.. 1988. "Two types of reservoir-Induced seismicity." Bulletin of the Seismological Society of America 2025-2040.

Thapa, D. R., 2018. Seismicity of Nepal and the Surrounding Region. Bulletin of the Department of Geology, 83-86. https://doi. org/10.3126/bdg.v20i0.20727
Trinh, N., \& Panthi, K., 2014. Evaluation of Seismic Events Occurred after Filling and Drawdown of the Reservoir at Song Tranh 2 HPP in Vietnam. Hydro Nepal: Journal of Water, Energy, and Environment, 15, 16-20. https://doi.org/10.3126/hn.v15i0.11285

Talwani, P., 1997. On the Nature of Reservoirinduced Seismicity. Seismicity Associated with Mines, Reservoirs, and Fluid Injections, 473-492. https://doi.org/10.1007/978-30348-8814-1_8

Upreti B. N., Kumahara Y., and Nakata T., 2007. Paleoseismological Study In The Nepal Himalaya - Present Status. Proceedings of the Korea-Nepal Joint symposium on slope stability and landslides April 1, 2007, p. 1-9.

Wei, H., Wang, M., Song, B., Wang, X., and Chen. D. 2018. "Study on the Magnitude of Reservoir-Triggered Earthquake Based on Support Vector Machines." Complexity 10. 